San Jose State University

SJSU ScholarWorks

Master's Theses

Master's Theses and Graduate Research

1992

\title{
Biochemical and morphological evidence for a newly introduced species of Aurelia in San Francisco Bay, California
}

Nina Greenberg

San Jose State University

Follow this and additional works at: https://scholarworks.sjsu.edu/etd_theses

\section{Recommended Citation}

Greenberg, Nina, "Biochemical and morphological evidence for a newly introduced species of Aurelia in San Francisco Bay, California" (1992). Master's Theses. 461.

DOI: https://doi.org/10.31979/etd.3cep-ycvw

https://scholarworks.sjsu.edu/etd_theses/461

This Thesis is brought to you for free and open access by the Master's Theses and Graduate Research at SJSU ScholarWorks. It has been accepted for inclusion in Master's Theses by an authorized administrator of SJSU ScholarWorks. For more information, please contact scholarworks@sjsu.edu. 


\section{INFORMATION TO USERS}

This manuscript has been reproduced from the microfilm master. UMI films the text directly from the original or copy submitted. Thus, some thesis and dissertation copies are in typewriter face, while others may be from any type of computer printer.

The quality of this reproduction is dependent upon the quality of the copy submitted. Broken or indistinct print, colored or poor quality illustrations and photographs, print bleedthrough, substandard margins, and improper alignment can adversely affect reproduction.

In the unlikely event that the author did not send UMI a complete manuscript and there are missing pages, these will be noted. Also, if unauthorized copyright material had to be removed, a note will indicate the deletion.

Oversize materials (e.g., maps, drawings, charts) are reproduced by sectioning the original, beginning at the upper left-hand corner and continuing from left to right in equal sections with small overlaps. Each original is also photographed in one exposure and is included in reduced form at the back of the book.

Photographs included in the original manuscript have been reproduced xerographically in this copy. Higher quality $6^{\prime \prime} \times 9^{\prime \prime}$ black and white photographic prints are available for any photographs or illustrations appearing in this copy for an additional charge. Contact UMI directly to order.

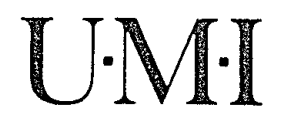



Order Number 1351032

Biochemical and morphologial evidence for a newly introduced species of Aurelia in San Francisco Bay, California

Greenberg, Nina, M.S.

San Jose State University, 1992 

BIOCHEMICAL AND MORPHOLOGICAL EVIDENCE FOR

A NEWLY INTRODUCED SPECIES OF AURELIA

IN SAN FRANCISCO BAY, CALIFORNIA

\author{
A Thesis \\ Presented to \\ The Faculty of the Department of \\ Moss Landing Maring Laboratories \\ San Jose State University \\ In Partial Fulfillment \\ of the Requirements for the Degree \\ Master of Sciences
}

By

Nina Greenberg

December, 1992 


\section{APPROVED FOR THE DEPARTMENT OF}

MOSS ILANDING-MARINE LABORATORIES

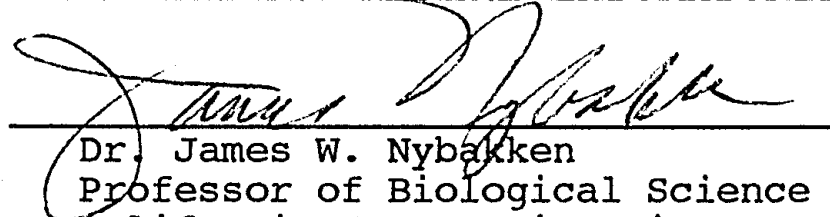

California State Uniyersity, Hayward

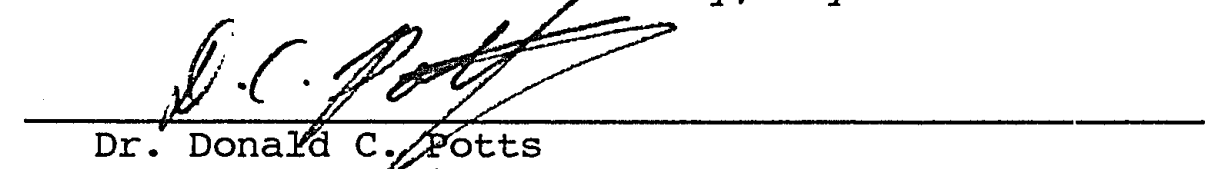
Professor of Biology Iniversity of California, Santa Cruz

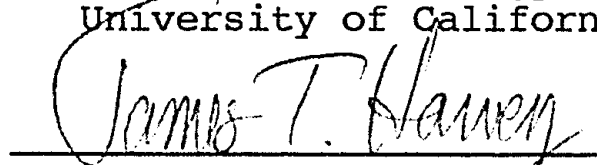

Dr. James T. Harvey

Assistant Professdy of Marine Science California State Uniyersity, Hayward

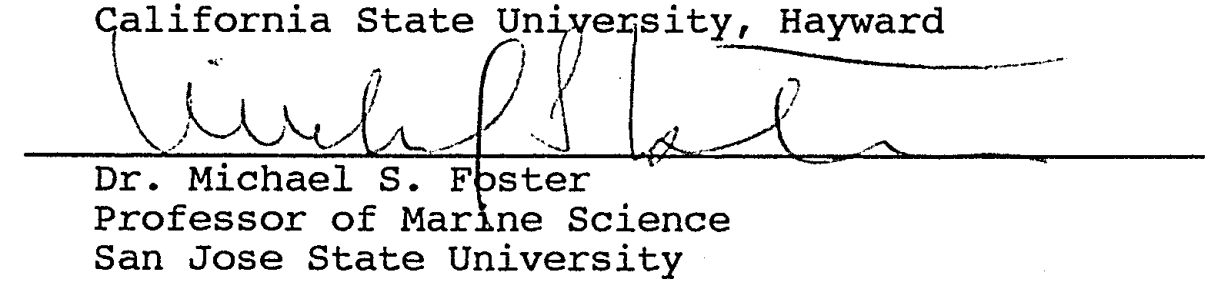

\section{APPROVED FOR THE UNIVERSITY}

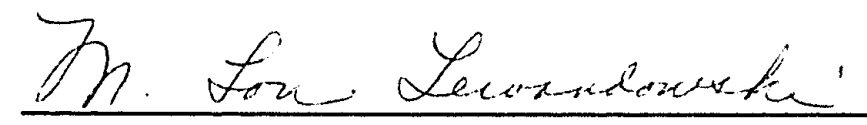




\section{ABSTRACT \\ BIOCHEMICAL AND MORPHOLOGICAL EVIDENCE FOR \\ A NEWLY INTRODUCED SPECIES OF AURELIA \\ IN SAN FRANCISCO BAY, CALIFORNIA \\ by Nina Greenberg}

The jellyfish Aurelia aurita is widely considered to be a 'cosmopolitan' species, and a major component of nearshore plankton communities worldwide. Large annual aggregations have occurred at Foster City, in southern San Francisco Bay, California, since 1988. These Aurelia are morphologically similar to aquarium-cultured Japanese Aurelia, but distinct from Aurelia in Monterey Bay, 200 kilometers south of San Francisco Bay. Starch gel enzyme electrophoresis strongly suggests that Foster City and Tokyo Bay Aurelia are the same species, while Monterey Bay and Vancouver Island Aurelia are a second, distinct species. These species can also be distinguished by features of their radial canal systems. It is proposed that Foster City's Aurelia are a recent introduction, probably from Japan via ship's ballast water. 
ACKNOWLEDGEMENTS

My sincere appreciation and thanks go to all those who provided the following indispensable support that made this research possible: funding by the Dr. Earl H. Myers and Ethyl M. Meyers Oceanographic and Marine Biology Trust, the LernerGrey Fund for Marine Research, and the Packard Foundation; laboratory support by Ron Garthwaite and Don Potts at the University of California, Santa Cruz; animal Collections supported by Cathy Carolsfeld of WestWind SeaLab Supplies, Gregg Collins of Foster City Municipal District, and Jeff Gomas of Ocean View Marine; photographic support by Craig Racicot; and support for illustrations by Annaliese Miller. 


\section{TABLE OF CONTENTS}

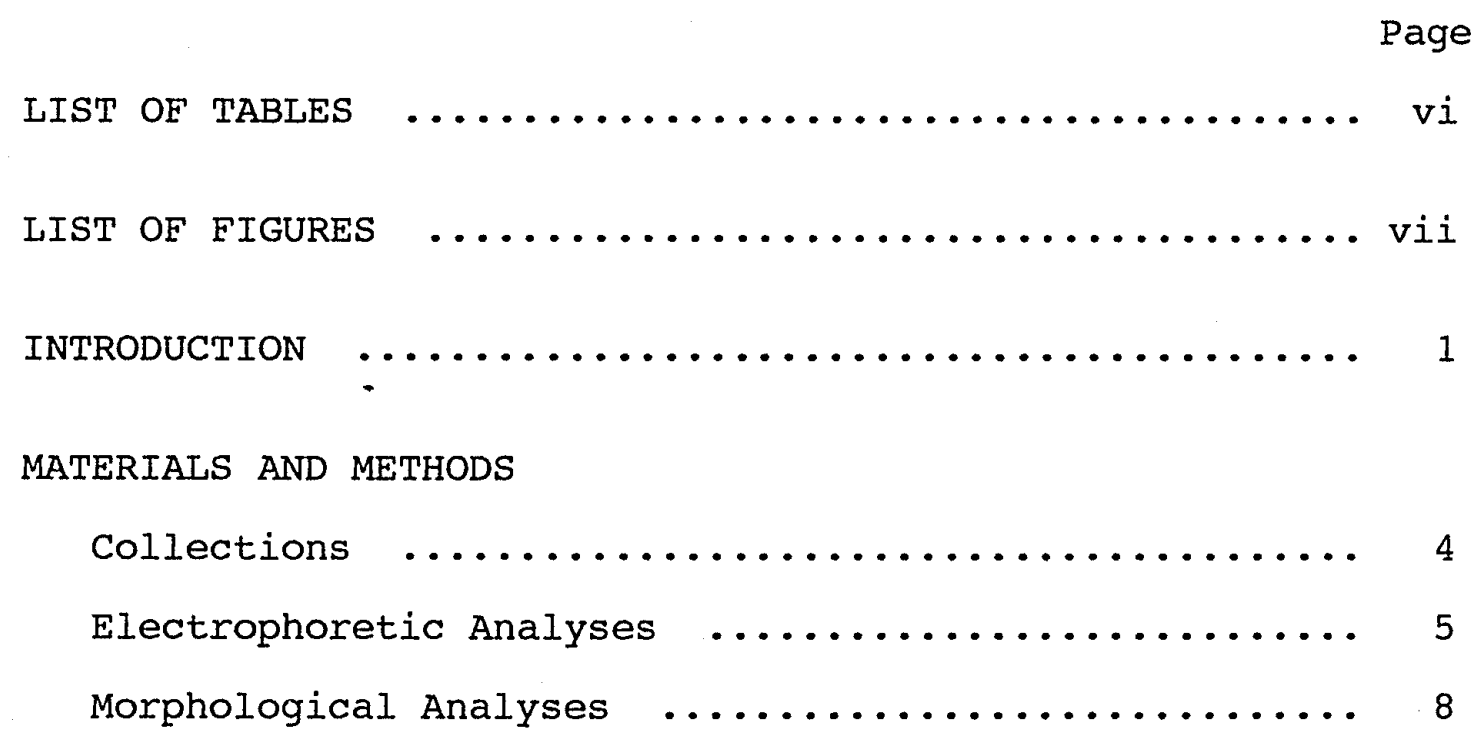

RESULTS

Electrophoretic Analyses $\ldots \ldots \ldots \ldots \ldots \ldots \ldots \ldots \ldots \ldots$

Morphological Analyses $\ldots \ldots \ldots \ldots \ldots \ldots \ldots \ldots \ldots$

DISCUSSION $\ldots \ldots \ldots \ldots \ldots \ldots \ldots \ldots \ldots \ldots \ldots \ldots \ldots \ldots \ldots \ldots \ldots \ldots \ldots \ldots$

LITERATURE CITED $\ldots \ldots \ldots \ldots \ldots \ldots \ldots \ldots \ldots \ldots \ldots \ldots \ldots \ldots$ 


\section{LIST OF TABLES}

Table

Page

1. Aurelia samples listed by collection site and date, with the number of animals biochemically analyzed, the number of unique genotypes sampled, the total number of medusae examined morphologically, and the number of medusae examined within a bell radius size range of

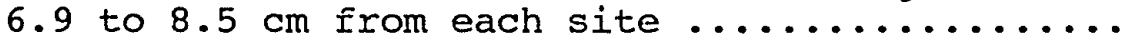

2. Aurelia spp. Allele frequencies at 20 loci from $\mathrm{VI}=$ Vancouver Island, British Columbia; $\mathrm{MB}=$ Monterey Bay, Calif.; FC = Foster City, Calif.; $\mathrm{TB}=$ Tokyo Bay, Japan; $\mathrm{J}=$ aquarium-cultured Japanese. $\mathrm{n}=$ number of individuals. Alleles of scored loci for $J$ (where $n=1$ ) are listed symbolically as present $(Y)$ or absent $(-) \ldots \ldots$

3. Aurelia spp. Matrix of Nei's genetic distances (D) above diagonal. and identities (I) below diagonal among four sites: VI = Vancouver Island, British Columbia; $\mathrm{MB}=$ Monterey Bay, Calif.; $\mathrm{FC}=$ Foster City, Calif.; TB = Tokyo Bay, Japan .... 
LIST OF FIGURES

Figure

Page

1. Sampling sites $\ldots \ldots \ldots \ldots \ldots \ldots \ldots \ldots \ldots \ldots \ldots \ldots$

2. Means (dot), standard errors (box) and range (bar)

of radial canal structures of Aurelia medusae

within a bell radius size range of 6.9 to $8.5 \mathrm{~cm}$

3. Octants of radial canals of similarly sized medusae from Monterey Bay (bell radius $=7.8 \mathrm{~cm}$; number of divergence points $=192$, convergence points $=153$, and total intersecting points $=345$ ) and Foster City (bell radius $=7.9 \mathrm{~cm}$; number of divergence points $=30$, convergence points $=12$, and total intersecting points $=42) \ldots \ldots \ldots \ldots \ldots \ldots \ldots \ldots$

4. Means (dot), standard errors (box) and range (bar) of manubrium lengths of Aurelia medusae within a bell radius size range of 6.9 to $8.5 \mathrm{~cm} \ldots . . .40$

5. Aurelia medusa divergence (a), convergence (b) and total intersecting (c) points of radial canal octants plotted against bell radius with corresponding regression lines for North American and Asian groups; and manubrium length (d) plotted against bell radius with correspponding regression lines for each site .. 
INTRODUCTION

The common moon jellyfish Aurelia aurita (Linnaeus 1758) is considered a "cosmopolitan" species with a worldwide distribution in warm and temperate waters (Russell 1970). It has a typical cnidarian life history in which minute, benthic, asexual polyps alternate with large, planktonic, sexual medusae (Barnes 1987). Aggregations of A. aurita medusae are major components of numerous neritic plankton communities as predators (Moller 1979, 1980a, 1984; Lindahl and Hernroth 1983; Veer 1985; Veer and Oorthuysen 1985; Hay et al. 1990) and pests (Matsueda 1969, Rasmussen 1973, Yasuda 1979, Hay et al. 1990). Aggregations of A. aurita are common in summer in protected bays and estuaries where reproduction occurs (Yasuda 1979, Moller 1980b, Lindahl and Hernroth 1983, Shushkina and Musayeva 1983, Shenker 1984, Sloan and Gunn 1985, Veer and Oorthuysen 1985, Papathanassiou et al. 1987, Roden et al. 1990).

In California, annual blooms are common in Tomales Bay, $100 \mathrm{~km}$ north of San Francisco (Hamner and Jenssen 1974) and Monterey Bay, $200 \mathrm{~km}$ south of San Francisco (pers. obs.). Annual blooms also have occurred in a lagoon at Foster City, in the southern part of San Francisco Bay, since spring of 1988 when they were first noted (G.W. Collins, Foster City Municipal District, pers. comm.). 
Marine communities in the shallow parts of South san Francisco Bay are now largely dominated by species introduced over the past 130 years from the Atlantic and Western Pacific via ballast water, fouling on ships, and by incidental importation with commercial species (Carlton 1979). The rate of introductions to San Francisco Bay is currently estimated by Carlton et al. (1990) at one species per year.

The twentieth century history of Aurelia taxonomy has been characterized by reduction of numbers of recognized species by synonymy: Mayer (1910) recognized twelve Aurelia species; Kramp (1961) recognized seven; but currently only two, Aurelia limbata (Brandt 1838) and A. aurita are recognized (Russell 1970, Kozloff 1987). Early species descriptions generally were non-quantitative and based on few or single specimens (Mayer 1910). Morphological variation and intergradation between forms have been the primary reasons for synonymizing species (Russell 1970, Kramp 1961). Of the two species now recognized, A. limbata is considered to be a rare, polar species recognized by a distinct brown bell margin (Kozloff 1987) and greatly anastomosing radial canals (Bigelow 1913); A. aurita includes all other moon jellyfish (Russell 1970).

In the North Pacific, Uchida (1954) reported that $\underline{\text { A. }}$ aurita was common in the warmer southern waters of Japan and A. limbata was common in the colder northern waters of Japan. 
By contrast, all recent reports of Aurelia on the Pacific coast of North America refer only to A. aurita (Hamner and Jenssen 1974, Shenker 1984, Sloan and Gunn 1985). However, my preliminary observations in central California indicated that the purple hue and extensive manubrium of Aurelia from Monterey Bay enabled them to be readily distinguished from the more translucent Aurelia with shorter manubriums from Foster City. Aurelia in Foster City much more closely resembled the Japanese A. aurita under culture in the Monterey Bay Aquarium.

These observations, considered within the general context that many marine communities in South San Francisco Bay are dominated by introduced species (Carlton 1979) raised three questions addressed in this study: (1) Are the Foster City and Japanese Aurelia the same species, and a different species from the Monterey Bay Aurelia? (2) If so, are there morphological features that can be used for consistent species identification? (3) Do Aurelia at Foster City represent a newly introduced species to the North American Pacific coast? 
MATERIALS AND METHODS

\section{Collections}

In British Columbia and California (Fig.1), individual medusae were haphazardly collected with dip-nets from boats or piers or caught in bags by snorkelers. The area of each collection site was approximately $1 \mathrm{~km}^{2}$. Details of localities, dates and numbers of animals collected are given in Table 1. Tissue samples for electrophoresis consisted of tentacles pinched or cut from each medusa. After excess moisture was absorbed on paper towels, the tissues were placed in pre-marked plastic vials on dry ice, and transported to the University of California, Santa Cruz for storage at $-70^{\circ} \mathrm{C}$.

Japanese medusae were sampled in two ways. First, tentacle tissue samples were taken from Japanese medusae that have been cultured at the Monterey Bay Aquarium since 1985 (M.A. Ferguson, Monterey Bay Aquarium, pers. comm.). Tissue samples were taken on 11 December 1990 and 20 March 1991. These medusae were asexual progeny of animals originally collected by personnel of the Ueno Zoo Aquarium in Tokyo, Japan (M.A. Ferguson, pers. comm.). Second, a shipment was received on 11 November 1990 of live juvenile medusae caught (just prior to shipment) in Tokyo Bay, Japan (Fig. 1). These animals were reared to larger size in tanks. Tentacle tissue 
samples were taken on 11 December 1990, 23 January 1991 and 20 March 1991.

For subsequent morphologic analyses, the medusae from Tokyo Bay and additional live medusae from Foster City, Monterey Bay and Vancouver Island (Table 1) were maintained in flow-through tanks at the Monterey Bay Aquarium; they were fed newly hatched Artemia nauplii, enriched with Selco ${ }^{\circledR}$, approximately five days per week.

\section{Electrophoretic Analyses}

Small amounts (about $5 \mathrm{~mm}^{3}$ ) of tentacular tissue and an equal volume of homogenizing buffer (Stoddart 1983) were sonicated in short bursts for a total of $1-3$ seconds and then centrifuged at $11,000 \mathrm{rpm}$ for 2 minutes at $10^{\circ} \mathrm{C}$. Twenty-three enzymes were surveyed with horizontal starch gel electrophoresis using Sigma starch and $9 \times 5 \mathrm{~mm}$ Whatman \#2 filter paper wicks.

Buffer system II (Selander et al. 1971) was used to survey for glutamate dehydrogenase (GTDH), leucyl-proline peptidase (PEPLP), leucyl-glycyl-glycine peptidase (PEPLGG), glycly-leucine peptidase (PEPGL), esterases (EST), 3hydroxybutyrate dehydrogenase (HBDH), hexokinase (HK), fructose biphosphatase (FBP), mannose 6-phospate dehydrogenase $(\mathrm{M} 6 \mathrm{PDH})$, xanthine dehyrodgenase $(\mathrm{XDH})$, leucine aminopeptidase (LAP) and superoxide dismutase (SOD, scored as 
an artifact on $\mathrm{M} 6 \mathrm{PDH}, \mathrm{FBP}$, or $\mathrm{XDH}$ ). Buffer system IV (Selander et al. 1971) was used to survey for catalase (CAT), esterase-D (ESTD), fumarate hydratase(FUMH), malate dehydrogenase $(\mathrm{MDH})$, isocitrate dehydrogenase (IDH), purine nucleoside phosphorylase (PNP), NADP dependent MDH (MDHP), acid phosphatase ( $A C P)$, phosphogluconate dehydrogenase $(\mathrm{PGDH})$, aspartate aminotransferase (AAT), and phosphoglucomutase (PGM). Stain recipes were taken from Hillis and Moritz (1990) and Aebersold et al. (1987) with minor modifications.

While activity was present at AAT, HBDH, M6PDH, HK, PGM, $\mathrm{FBP}$ and $\mathrm{XDH}$, it was inconsistent and these enzymes were omitted from the analyses. Banding patterns at IAP and MDHP-2 loci were not interpretable as mendelian loci. Banding patterns from 15 enzymes (20 loci) were interpretable and scored as allelic variation at mendelian loci. At each locus, the allele with the fastest mobility was designated '100'; all others were named by subtracting their deviation (in millimeters) in mobility from this reference allele.

To exclude possibile clonemates within samples, duplicate individuals that were genotypically identical at all loci were excluded, so that each multi-locus genotype was represented only once in the statistical analyses. Sample sizes and allele frequencies for the 20 scorable loci in the Vancouver Island, Foster City, Monterey Bay and Tokyo Bay 
populations are given in Table 2. Exclusion of individuals that were not genotypically unique reduced sample sizes $13 \%$ for Monterey Bay $(n=20), 26 \%$ for Vancouver Island $(n=17), 50 \%$ for Foster City $(n=12), 55 \%$ for Tokyo Bay $(n=5)$, and $92 \%$ for the aquarium-reared Japanese animals ( $n=1$, Table 1). Small deviations in these sample sizes at some loci resulted from a few unscorable individuals or gels.

Testing with the binomial tables of Mainland et al. (1956) found no significant differences in allele frequencies at any locus between the two collection dates for Foster City, and among the five collection sites and two dates at Vancouver Island. Therefore, these samples were pooled. The significance of allele frequency differences at each locus among all possible pairs of four sites (Foster City, Vancouver Island, Monterey Bay, and Tokyo Bay) were tested using the binomial tables of Mainland et al. (1956). Nei's unbiased estimate of genetic distance (D) and genetic identities (I) from a small number of individuals (Nei 1978) were calculated for all possible pairs of sites. The aquarium-cultured Japanese medusae were excluded from genetical tests of statistical significance because they were represented by a single genotype; however, their enzyme banding patterns were compared qualitatively to other sites. 
Morphological Analyses

Preliminary examinations of medusae from each site included the following morphological features: radial canal structure; manubrium length and shape; bell and gonad color; rhopalia structure; rhopalial and inter-rhopalial notch size; subgenital ostia size and shape; and oral arm size and shape. All features, except radial canal structure and manubrium length, were highly variable within sites; changed with sexual maturity, age, or size; or were difficult to quantify. Therefore, radial canal structure and manubrium length were the only features quantified for morphological comparisons.

Quantification of radial canal structure and manubrium length was performed on: 8 medusae from Monterey Bay, 4 from Vancouver Island; 10 from Foster City, and 4 from Tokyo Bay (Table 1). These medusae were maintained alive in aquaria from their time of capture (Table 1) until 9 september, 1991. At this time, canal systems of each live medusa were photographed in subumbrellar views. The bell radius $(R$, measured along the flattened subumbrella surface from the center of the manubrium to the bell margin) and the manubrium length $(M)$ were measured and recorded. The medusae were then fixed in $20 \%$ formaldehyde for 20 minutes and preserved in $10 \%$ formaldehyde.

To quantify radial canal structure, images on photographic slides were projected onto paper and an octant 
of the canal system was traced for each medusa. Canals were traced as lines without width. Then, every point where the canals diverged (D) or converged (C) from the bell center to the bell margin, was marked and counted. Canals that diverged at angles close to $90^{\circ}$ often converged with adjacent canals. In these instances, one was arbitrarily designated as a divergence point and the other as a convergence point. Total intersections ( $T$ ) were calculated as the sum of all divergence and convergence points for each medusa. In four Monterey Bay medusae, the canal systems were not visible on slide images. Therefore, after preservation, each (of these four medusae) was placed in a separate sealed plastic bag. An octant from a subumbrellar view of its canal system was then traced directly onto a plastic sheet with a permanent marker before counting divergence and convergence points.

Bell radius was used as a general measure of size. Normality of $\mathrm{R}$ was assessed graphically for each site. Equality of variances (F-tests) and means (t-tests) were tested between Monterey Bay and Vancouver Island, and between Foster City and Tokyo Bay.. No significant differences were found between Monterey Bay and Vancouver Island (F-test, $p=0.315$; t-test, $p=0.534)$, nor between Foster City and Tokyo Bay (F-test, $p=0.250$; t-test, $p=0.534)$. Sites were pooled and equality of variance (F-test) and means ( $t$-test) between the 
two groups were tested. There was no significant differences between means $(p=0.064)$, but there was significant differences in variances $(p=0.024)$. In order to test differences in canal structure and manubrium length between medusae of similar sizes, medusae in non-overlapping size ranges were graphically determined ( $R<6.9$ and $R>8.5 \mathrm{~cm}$ ) and excluded.

Remaining sample sizes for testing differences in canal structure $(D, C$, and $T$ ) and manubrium length $(M)$, were $n=5$ in Monterey Bay, $n=4$ in Vancouver Island, $n=4$ in Foster City, and $n=4$ in Tokyo Bay (Table 1 ). Normality of $D, C, T$, and $M$ were assessed graphically at each site. Equality of variances (F-tests) and means (t-tests) were tested between Monterey Bay and Vancouver Island, and between Foster City and Tokyo Bay (Zar 1984). Effect size $\left(d_{s}\right)$ and power for each test of equality of means (t-tests) with non-significant results was estimated at a sample size of $n=8$ because this was the smallest tabeled sample size $\left(a_{2}=.05\right.$, Cohen 1988).

For $D, C$, and $T$, no differences in variances or means were found between Foster City and Tokyo Bay (F-tests: D, $\mathrm{p}>0.500 ; C, p=0.424 ; \mathrm{T}, \mathrm{p}>0.500$; t-tests: $\mathrm{D}, \mathrm{p}=0.462 ; \mathrm{C}$, $\mathrm{p}=0.104 ; \mathrm{T}, \mathrm{p}=0.188)$, and between Monterey Bay and Vancouver Island (F-tests: $D, p=0.346 ; C, p=0.438 ; T, p=0.367$; t-tests: D, $p=0.874 ; C, p=0.736 ; T, p=0.931)$. Power estimates between Foster City and Tokyo Bay were low (17\% at $D, d_{s}=0.56 ; 73 \%$ at 
C, $d_{s}=1.48 ; 498$ at $\left.T, d_{s}=1.05\right)$; power estimates between Monterey Bay and Vancouver Island were lower (5\% at D, $d_{s}=0.11 ; 8 \%$ at $c, d_{s}=0.24 ; 2.5 \%$ at $\left.T, d_{s}=0.06\right)$. Power $\geq 80 \%$ is considered sufficient to distinguish potential differences between samples (Cohen 1988). These low power estimates indicated sample sizes were insufficient to distinguish populations of the same species. Low power estimates were attributed to both small sample sizes and very small morphological differences (effect sizes) between populations of the same species. The estimated sample size sufficient to distinguish differences in $\mathrm{T}$ between Monterey Bay and Vancouver Island populations $\left(d_{s}=0.06\right.$, power $\left.=80, a_{2}=.05\right)$ is an $n>1000$ (Cohen 1988). Although power was low, Monterey Bay and Vancouver Island, and Foster City and Tokyo Bay sites were pooled. Equality of variances (F-test) and means (MannWhitney U-test) between pooled groups were tested (Zar 1984).

For $M$, there were no significant differences in variances between Monterey Bay and Vancouver Island (F-test, $\mathrm{p}=0.479$ ) and between Foster City and Tokyo Bay (F-test, p>0.500), but there were significant differences in means between Monterey Bay and Vancouver Island (t-test, $p=0.004$ ), and between Foster City and Tokyo Bay (t-test, $p=0.010$ ). The separate four sites were tested for equality of variances (Cochran's test, Winer 1971) and means (Kruskal-Wallis test, Zar 1984). Pairwise multiple comparisons (Games-Howell test, 
Day and Quinn 1989) between all possible site combinations were performed.

To determine whether differences in medusae of bell radii of 6.9 to $8.5 \mathrm{~cm}$ also exist in medusae of other size classes, trends in the different variables with size were analyzed by plotting D, C, T, and $M$ against $R$ for each site, using every sampled medusa. For $D, C$, and $T$, equality of slopes of least squares regression lines to zero for each group (F-tests) and between groups ( $t$-tests) were tested. For $M$, equality of slopes of least squares regression lines to zero for each site (F-tests), among sites (analysis of covariance, F-test; Zar 1984), and between all possible site pairs (Tukey test, Zar 1984) were tested.

Preserved medusae from each site were deposited in the California Academy of Sciences in San Francisco, California: four from Monterey Bay (cat. nos. 081304-081307), five from Foster City (cat. nos. 081311-081315), two from Vancouver Island (cat. no. 086767), and two from Tokyo Bay (cat. nos. 081308-081309). Preserved medusae from each site were also deposited in the National Museum of Natural History, Washington, D.C.: four from Monterey Bay (cat. no. 92911), five from Foster City (cat. no. 92912), two from Vancouver Island (cat. no. 92913), and two from Tokyo Bay (cat. no. 92914). 
RESULTS

Electrophoretic Analyses

Fixed allelic differences (i.e. no alleles in common) separated medusae from different sites at 7 of 14 polymorphic loci (Table 2A: IDH-1, IDH-2, SOD-1, SOD-2, EST-1, EST-2, PNP). In every case, these loci separated medusae from the four field sites into two consistent groups: Foster City and Tokyo Bay in one; Monterey Bay and Vancouver Island in the other. In addition, there were significant $(\mathrm{p}<0.010)$ allele frequency differences separating the same two groups at 5 of the remaining 7 polymorphic loci (Table 2B: CAT, ESTD, PEPLGG, GTDH, PEPLP). Only two polymorphic loci had allele frequencies with no significant differences, although both differed in presence or absence of rare alleles between the two groups (Table 2C: PGDH, $\mathrm{MDH}-2$ ). Six loci were monomorphic, having the same homozygous allele present in every medusa from all sites (Table 2D: FUMH-1, FUMH-2, MDH-1, MDHP-1, ACP, PEPGL). Finally, although the LAP and MDHP-2 loci were not interpretable as mendelian loci, each group had a different fixed isozyme patterns for these loci.

The 13 Japanese individuals from aquarium culture were identical at every locus indicating that they were clonemates. They were heterozygous at only two loci, PNP and ESTD: three of their polymorphic alleles (PNP-98, ESTD-96, 
ESTD-100) were fairly common (frequency $\geq .20$ ) in both the Foster City and Tokyo Bay medusae; the fourth (PNP-100) was not present at any other site. At all other 18 loci, the cultured Japanese medusae were homozygous for the same alleles that were dominant (frequency >.80) or fixed at those loci in the Foster City and Tokyo Bay populations.

In summary, 12 of 20 mendelian loci $(7$ with fixed alleles, 5 with significant frequency differences), plus 2 norl-mendelian enzymes, all divide these jellyfish into two groups: one group (Asian) with western Pacific affinities from Foster City, Tokyo Bay and cultured Japanese medusae; and the other group (North American) with eastern Pacific affinities from Vancouver Island and Monterey Bay medusae. Within the Asian group, there were no significant differences in a.llele frequencies between Foster City and Tokyo Bay at any locus. However in the North American group, Vancouver Island and Monterey Bay were distinguished by a signficant $(p=0.010)$ allele frequency difference at a single locus (GTDH); although this may indicate a possible difference in populations, it also may have occurred by chance.

Nei's (1978) genetic distances (D) and genetic identities (I) were consistent with the existence of two distinct geographic groups (Table 3 ). Values of I within groups (between Monterey Bay and Vancouver Island $=.990$ and 
between Foster City and Tokyo Bay $=.992$ ), are consistent with conspecific comparisons in other taxa (Thorpe 1983). The four I values between groups $(.426-.500)$ are all consistent with interspecific but congeneric comparisons (Thorpe 1983).

\section{Morphological Analyses}

Radial canal counts (D, C, and $T$ ) of North American (Monterey Bay and Vancouver Island) medusae were much greater than those of Asian (Foster City and Tokyo Bay) medusae for bell radii of 6.9 to $8.5 \mathrm{~cm}$ (Fig. 2). For all three characters $(D, C, T)$ there were heterogeneous variances between the two groups (F-tests, $p<0.001$ ), and significant differences between means (Mann-Whitney U-tests, $p=0.0003$ ). These results indicate that these canal structure measures $(D, C, T)$ are all good morphologic features for distinguishing groups identified by enzyme electrophoresis. These differences in canal structure are easily seen in living and preserved animals. Radial canal octants of a medusa from Monterey Bay and one of similar size from Foster City are illustrated in Figure 3.

Manubrium lengths (M) among the four sites had significantly different variances (Cochran's test, $0.05>p>0.01$ ) and means (Kruskal-Wallis, $p<0.001 ;$ Fig.4) . Games-Howell pairwise comparisons indicated significant differences in manubrium length for all possible pairs of 
sites $(p<0.050)$. These results indicate that, for medusae with bell radii of $6.9-8.5 \mathrm{~cm}$, there is substantial variation of manubrium length among medusae from each site, but only slight overlap between groups (all Asian medusae $\leq 2.6 \mathrm{~cm}$; all North American medusae $\geq 2.6 \mathrm{~cm}$; Fig. 4). Thus, despite variation between sites, manubrium length will usually distinguish the same groups identified by enzyme electrophoresis.

Trends in canal structure (D, C, and T) with size (R) (Fig. 5a-c), indicate the Asian (Foster City and Tokyo Bay) medusae have a relatively fixed radial canal system that increases in complexity only slightly with growth. Slopes of regression lines fitted to Asian animals were all significantly greater than zero (F-tests: $D, p=0.005 ; C$, $p=0.012 ; T, p=0.004$ ). In North American (Monterey Bay and Vancouver Island) medusae, apparent trends of continued divergence and convergence with increasing size appear strong (Fig. 5a-c), but slopes of regression lines fitted to North American animals were not significantly greater than zero (F-tests: $D, p=0.069 ; C, p=0.115 ; T, p=0.085$ ). Although heterogeneity of variances in size (R) exist between Asian and North American medusae, slopes of regression lines fitted to North American animals were all significantly greater than those fitted to Asian animals (t-tests: $D, p=0.018 ; D$, $p=0.030 ; T, p=0.020$ ). These results indicate $D, C$ and $T$ can 
all be used to distinguish medusae larger than $8.5 \mathrm{~cm}$ in bell radius, but using them to distinguish medusae smaller than $6.9 \mathrm{~cm}$ in beil radius may not be possible.

Apparent trends in manubrium length with size (Fig. 5d), indicated that the manubrium grows at different rates at each site, with the fastest growth in the North American animals (Monterey Bay > Vancouver Island). Slopes of regression lines were significantly greater than zero for medusae from Monterey Bay (F-test, $\mathrm{p}=0.006$ ), but not in medusae from Vancouver Island (F-test, $\mathrm{p}=0.418$ ). In the Asian animals, manubrium length increases slightly with size, and at similar rates (Foster City $\approx$ Tokyo Bay). Slopes of regression lines were significantly greater than zero for medusae from Foster City (F-test, $p=0.0002$ ), but not in medusae from Tokyo Bay (F-test, $p=0.613)$. Analysis of co-variance indicated significant difference among all four slopes (F-test, $\mathrm{p}=0.042$ ) and Tukey pairwise comparisons indicated only one significant difference in slopes of regressions lines between Monterey Bay and Foster City medusae $(p=0.006)$. These results indicate manubrium length can be used to distinguish Monterey Bay and Foster City medusae larger than $8.5 \mathrm{~cm}$ in bell radius, but using manubrium length to distinguish medusae from these sites smaller than $6.9 \mathrm{~cm}$ in bell radius may not be possible. 
DISCUSSION

Electrophoretic data from the four sample sites clearly delineate two groups of Aurelia, one consisting of Monterey Bay and Vancouver Island, and the other Foster City and Tokyo Bay (Table 2). Fixed alleles separated the two groups at 7 of 20 scored mendelian loci. Fixed alleles indicate absolute barriers to gene flow (Avise 1975) which agree with specieslevel differences between sites. Significant allele frequency differences at 5 of the remaining $/$ polymorphic loci also support species-level differences. In addition, 2 enzymes had unique, non-overlapping patterns that could not be resolved as mendelian patterns. Thus, 14 (64\%) of 22 loci were polymorphic, and $12(86 \%)$ of these differed consistently between the groups. Together, this is compelling evidence that each Aurelia group is a distinct species. Nei's genetic identity "I" is commonly used to express overall electrophoretic similarity. In general, for invertebrates, vertebrates and plants, I values above .90 indicate conspecific populations, I values between .25 and .85 indicate congeneric species, and I values below .3 indicate confamilial genera (Thorpe 1983). In this study, I values between groups ranged from .473 to .500 ; while I values within groups were .990 and .992 (Table 3 ). These I 
values also indicate that each Aurelia group is a distinct species.

Nei's "I" is related to Nei's genetic distance "D" $(D=-\ln I)$; and empirical evidence suggests that $D$ increases linearly with time (Thorpe 1983). Although it varies considerably among taxa, a $D$ value of one is considered roughly equivalent to $18-20$ million years (Thorpe 1983). Thus, the $D$ values between these Aurelia species of .693 to .750 (Table 3), suggests that they may have diverged from a common ancestor approximately 12 to 15 million years ago in the Miocene.

Although calibration of molecular clocks is much more controversial, criteria for interpreting enzyme banding patterns as allele frequencies to distinguish populations, species and genera are generally accepted (Avise 1975, Ayala 1983, Thorpe 1983). Within the phylum Cnidaria, enzyme electrophoresis has been used to delineate morphologically similar taxa in both anthozoans (Bucklin and Hedgecock 1982, Bucklin 1985, Sole-Cava et al. 1985, Shaw et al. 1987, Smith and Potts 1987, Sole-Cava and Thorpe 1992, Garthwaite et al. In Press) and hydrozoans (Ostman 1982, Buss and Yund 1989). This study, however, may be the first use of enzyme electrophoresis to elucidate taxonomic relationships in a scyphozoan. 
The life-cycle of Aurelia, like most cnidarians, includes asexual reproduction. Thus, potential problems of clones within populations must be considered. In this study, all individuals with duplicate genotypes were excluded in the statistical analyses. The consequent reduction in sample sizes was not a major problem for identifying species. A large proportion of the common alleles of a species is contained within any one individual, so that, providing the number of loci scored is large, very few individuals are actually required to distinguish species qualitatively (Avise 1975), especially when fixed differences exist at many loci. In this study, the 20 loci plus 2 non-mendelian isozymes sampled from 5 to 20 unique genotypes per site (Table 1) were more than adequate to distinguish species differing at $64 \%$ of sampled loci.

The morphological analyses indicated, at least for medusae with bell radii of 6.9 to $8.5 \mathrm{~cm}$, three measurements of radial canal structure $(D, C, T)$ are all good morphological features to reliably distinguish the species originally separated by enzyme electrophoresis (Fig. 2). Although less sensitive, the manubrium length also separates most individuals in this size range (Fig. 4).

Analyses of plots of $D, C$ and $T$ against bell radius (Fig. 5a-c) indicated these features can also distinguish medusae larger than $8.5 \mathrm{~cm}$, but using them to distinguish 
medusae smaller than $6.9 \mathrm{~cm}$ may not be possible. These plots and statistically significant regression slopes indicate the Asian medusae have a relatively fixed radial canal system that increases only slightly in divergence and convergence with growth. In contrast radial canal systems of the North American group, although highly variable, appear to continue to increase in divergence and convergence as they grow. However, D, C and T did not change significantly with size, for the North American medusae, therefore individuals may have fixed radial canal systems throughout life. An alternative explanation is inadequate sampling restricted both in number and to a small size range $(\approx 3 \mathrm{~cm}$ in bell radius). Personal observations of the radial canals of medusae reared from polyps that were progeny of medusae collected on Vancouver Island and polyps collected on the Channel Islands do indicate medusae begin life with very simple radial canal systems that continue to increase in complexity as they grow. Although these observations support apparent, but statistically non-significant, trends in canal structure with growth for North American medusae, further sampling of larger and smaller medusae is needed for confirmation of these trends. Further sampling of smaller individuals is particulary important to determine the smallest size at which radial canals can be used to reliably distinguish species separated by enzyme electrophoresis. 
Analyses of plots of manubrium length against bell radius (Fig. 5d) indicated manubrium length can distinguish Monterey Bay and Foster City medusae larger than $8.5 \mathrm{~cm}$ in bell radius. Using manubrium length to distinguish medusae from these sites smaller than $6.9 \mathrm{~cm}$ in bell radius may also not be possible. Figure 5d suggests that the manubrium grows at different rates at each site, with the fastest growth in the North American animals (Monterey Bay > Vancouver Island), and slight growth in the Asian animals (Foster City = Tokyo Bay). However, slopes of regression lines were only significant for medusae from Monterey Bay and Foster City. These sites were also significantly different from each other. Thus, conclusive results for manubrium length are limited to these sites. Non-significance in slopes of regression lines for Vancouver Island and Tokyo Bay medusae may be due to inadequate sample sizes $(n=4)$ and Iimited size classes $(\approx 1-2 \mathrm{~cm}$ in bell radius). Inadequate sampling may also account for differences in $M$ between Monterey Bay and Vancouver Island, and between Foster City and Tokyo Bay. Alternatively, these differences may be real genotypic or phenotypic differences among populations of the same species. Further sampling of larger and smaller medusae from Vancouver Island and Foster City is needed to determine trends in the manubrium with size at these sites. In addition, further sampling of smaller individuals from all sites is particulary 
important to determine the smallest size at which manubrium lengths can be used to distinguish species separated by enzyme electrophoresis.

In addition to limitations in sample sizes and size ranges for this study's morphological analyses, animal collections were also limited to a single location, time and place. Due to possible sampling biases in this study, further morphological analyses should strive to maximize all of these factors.

Although some medusae have the potential to shrink (Hamner and Jenssen 1974), it is not known whether this involves reduction of complexity in existing canal systems or proportionate reduction in manubrium size. A possible related complication for this study's morphologic analyses is the variable lengths of time (from 2 to 12 months) that medusae from different sites were maintained in aquaria before analysis. However, shrinkage and general decline in health was observed only in the Tokyo Bay specimens. Observations by J.A. Gomas (Ocean View Marine, pers. comm.) of shrunken medusae indicated that while divergence angles may change, the number of divergence, convergence and total intersecting points do not. However, the medusae bell may shrink faster than the manubrium.

of the three quantified canal features, the total number of intersecting points may be the best for species 
identification. This is due to the difficulty in distinguishing divergence from convergence points in some instances. Total interesecting points ranged were from 27 to 81 in the Asian group, with a mean of 39 . In the North American group, total intersecting points ranged from 158 to 370 , with a mean of 222 .

Observations of the radial canals also indicated possible structural differences in the number of distinct radial canals arising from gastric pouches; in degree of peripheral convergences in the central adradial, interradial and perradial canals; and in the overall ratio of convergence to divergence points (Fig. 3). However, these features may also be size- or age-dependent.

Other observations of medusae reared in aquaria for display purposes indicated possible consistent and quantifiable differences in increased longevity of North American versus Asian Aurelia (J.A. Gomas, pers. comm.; pers. obs.). Testing these differenes and additional reproductive criteria for distinguishing species, e.g. the potential for cross fertilization, and the viability and fertility in the F-1 generation, was beyond the scope of this study. However, the biochemical criteria for divergence so strongly support the hypothesis of no gene flow between the two groups, there is no reason to doubt the conclusion that the Foster City and 
Tokyo Bay Aurelia are one species, while the Monterey Bay and Vancouver Island Aurelia are a second, distinct species.

Comparisons of the morphological differences defined in this study with drawings of radial canal structures and taxonomic descriptions of A. aurita in Kozloff (1974), Russell (1970), Kramp (1961), Bigelow (1913), and Mayer (1910), suggest possible names for each group among previously described species. However, I am purposefully withholding speculation about their identities until more rigorous taxonomic work is completed, including comparisons with type specimens. Given conflicting reports of the supposed rarity of A. limbata (Uchida 1954), and its identifying dark bell margin (Russell 1970), establishment of the correct species names must include the verification of $\underline{A}$. limbata as a distinct species.

My field observations of Aurelia on the American northwest and central Pacific coasts indicated that the species found in Monterey Bay and Vancouver Island has a broad distribution throughout this region. This statement is supported by personal observations of medusae with similar radial canal structures from several locations in Monterey Bay in several consecutive years (1989 to 1992); a single mature medusa found near the Channel Islands and numerous juvenile medusae raised from polyps (J.A. Gomas, pers. comm.) taken from the Channel Islands (R.S. Anderson, University of 
California, Santa Barbara, pers. comm.); three preserved specimens collected in 1974 near the Farallones, $40 \mathrm{~km}$ offshore of San Francisco bay (California Academy of Sciences: Cat.no. 000020); numerous preserved specimens collected in 1968 in Tomales Bay, California (Bodega Marine Laboratory); and numerous medusae observed at the five listed study sites on Vancouver Island. By contrast, the species found in Foster City lagoon appears to be an isolated population first seen in 1988 and not reported in any other nearby locality. (G.W. Collins pers. comm.).

These observations are consistent with Carlton's (1987) conclusion that introductions of new species are most likely in shallow, estuarine receiver areas such as San Francisco Bay. Likely donor regions to San Francisco Bay are Asia and Europe, based on current patterns of transport of ballast water on ships. Although Aurelia could be introduced as sessile stages fouling ship bottoms or other hard substrata, transportation of larvae or juveniles in ballast water seems the most likely mode of introduction because Aurelia is known to thrive in euryhaline, eurythermal, anoxic and industrially polluted waters (Matsueda 1969, Papathanassiou et al. 1987). The date, place of origin and mode of introduction of Foster City's moon jellyfish will probably never be known. However, a more extensive investigation of Aurelia taxonomy and distribution is important to confirm that the Foster City 
Aurelia is an isolated population, and to track and model the spread of an introduced species. This is particularly important considering Monterey Bay's recent declaration as a national marine sanctuary and future management efforts for preserving endemic species assemblages. To decrease probabilities of species introductions such efforts may include regulating release of foreign ballast water in offshore versus near-shore environments (J.T. Carlton, Williams College - Mystic Seaport, pers. comm.). Further investigations of Aurelia taxonomy and distribution may also provide a greater understanding of speciation processes in animals with similar complex life histories. 


\section{LITERATURE CITED}

Aebersold, P.B., G.A. Winans, D.J. Teel, G.B. Milner, and F.M. Utter. 1987. Manual for starch gel electrophoresis: a method for the detection of genetic variation. NOAA Technical Report NMFS 61:1-19.

Avise, J.D. 1975. Systematic value of electrophoretic data. Syst. Zool. 23:465-481.

Ayala, F.J. 1983. Enzymes as taxonomic characters. In: Protein polymorphism: adaptive and taxonomic significance, pp. 3-26. Ed. by G.S. Oxford and D. Rollinson. New York: Academic Press.

Barnes, R.D. 1987. Invertebrate zoology, 5th ed. pp. 118-121. Ed by R.D. Barnes. San Francisco: Saunders College Publishing.

Bigelow, H.B. 1913. Medusae and siphonophorae collected by the U.S. fisheries steamer "Albatross" in the northwestern Pacific, 1906. Proc. U.S. Nat. Mus. 44:98100 .

Bucklin, A. and D. Hedgecock. 1982. Biochemical genetic evidence for a third species of Metridium (Coelenterata: Actiniaria). Mar. Biol. 66:1-7.

Bucklin, A. 1985. Biochemical genetic variation, growth and regeneration of the sea anemone, Metridium, of British shores. J. Mar. Biol. Ass. U.K. 65:141-157.

Buss, L.W. and P.O. Yund. 1989. A sibling species group of Hydractinia in the North-Eastern United States. J. Mar. Biol. Ass. U.K. 69:857-874.

Carlton, J.T. 1979. Introduced invertebrates of San Francisco Bay. In: San Francisco Bay: the urbanized estuary, pp.427-444. Ed. by T.J. Conomos. San Francisco: California Academy of Sciences.

Carlton, J.T. 1987. Patterns of transoceanic marine biological invasions in the Pacific Ocean. Bull. Mar. Sci. 41:452-465. 
Carlton, J.T., J.K. Thompson, L.E. Schemel, and F.H. Nichols. 1990. Remarkable invasion of San Francisco Bay (California, USA) by the Asian clam Potamocorbula amurensis. I. Introduction and dispersal. Mar. Ecol. Prog. Ser. 66:81-94.

Cohen, J. 1988. Statistical power analysis for the behavioral sciences, $567 \mathrm{pp}$. Hillsdale, New Jersey: Lawrence Erlbaum Associates.

Day, R.W. and G.P. Quinn. 1989. Comparisons of treatments after an analysis of variance in ecology. Ecol. Monogr. $59: 433-463$.

Garthwaite, R.I., D.C. Potts, J.E.N. Veron and T.J. Done. In Press. Electrophoretic identification of Poritid species (Anthozoa: Scleractinia). Coral Reefs (In press).

Hamner, W.M. and R.M Jenssen. 1974. Growth, degrowth, and irreversible cell differenctiation in Aurelia aurita. Amer. Zool. 14:833-849.

Hay, S.J., J.R.G. Hislop and A.M. Shanks. 1990. North sea scyphomedusae; summer distribution, estimated biomass and significance particularly for O-group gadoid fish. Neth. J. Sea Res. 25:113-130.

Hillis, D.M. and C. Moritz. 1990. Molecular systematics, 588 pp. Sunderland, Massachusetts: Sinaur Associates.

Kozloff, E.N. 1987. Marine invertebrates of the Pacific Northwest, $511 \mathrm{pp}$. Seattle: University of Washington Press.

Kozloff, E.N. 1974. Keys to the marine invertebrates of puget sound, the San Juan Archipelago, and adjacent regions, $226 \mathrm{pp}$. Seattle: University of Washington Press.

Kramp, P.I. 1961. Synopsis of the medusae of the world. J. Mar. Biol. Assoc. U.K. 40:337-342.

Lindahl O. and Hernroth I. 1983. Phyto-zooplankton community in coastal waters of western Sweden - an ecosystem off balance? Mar. Ecol. Prog. Ser. 10:119-126.

Matsueda, N. 1969. Presentation of Aurelia aurita at thermal power station. Bull. Mar. Biol. Stat. Asamushi 13:187191. 
Mainland, D., L. Herrera, and M.I. Sutcliffe. 1956. Statistical tables for use with binomial samples -contingency tests, confidence limits, and sample size estimates, $83 \mathrm{pp}$. New York: Department of Medical Statistics, New York University College of Medicine.

Mayer, A.G. 1910. Medusae of the world, Carnegie Institution of Washington. Washington, D.C. Publ. 109, 3:603-630.

Moller, H. 1984. Reduction of larval herring population by jellyfish predator. Science 224:621-622.

Moller, H. 1980a. Scyphomedusae as predators and food competititors of larval fish. Meeresforsch 28:90-100.

Moller, H. 1980b. Population dynamics of Aurelia aurita medusae in Kiel Bight, Germany (FRG). Mar. Biol. 60: 123-128.

Moller, H. 1979. Significance of coelenterates in relation to other plankton organisms. Meeresforsch 27:1-18.

Nei, M. 1978. Estimation of average heterozygosity and genetic distance from a small number of individuals. Genetics 89:583-590.

Ostman, C. 1982. Isoenzymes and taxonomy in Scandinavian hydroids (Cnidaria, Campanulariidae). Zoologica Scripta $11: 155-163$.

Papathanassiou, E., P.Panayotidis, and K. Anagnostaki. 1987. Notes on the biology and ecology of the jellyfish Aurelia aurita Lam. in Elefsis Bay (Saronikos Gulf, Greece). P.S.Z.N.I. Marine Ecology 8:49-58.

Rasmussen, E. 1973. Systematics and ecology of the Isefjord marine fauna (Denmark). Ophelia 11:42-46.

Roden, C.I., R.R. Lohoefener, C.M. Rogers, K.D. Mullin and B.W. Hoggard. 1990. Aspects of the ecology of the moon jellyfish, Aurelia aurita, in the northern Gulf of Mexico. Northeast Gulf Sci. 11:63-67.

Russell, F.S. 1970. The medusae of the British Isles. Cambridge University Press. New York, N.Y. 2:139-140.

Selander, R.K., M.H. Smith, S.Y. Yang, W.E. Johnson, J.B. Gentry. 1971. IV. Biochemical polymorphism and systematics in the genus Peromyscus. I. Variation in the 
old field mouse (Peromyscus polionotus). Studies Genet. VI Univ. Texas Publ. 7103:49-90.

Shaw, P.W., J.A. Beardmore and J.S. Ryland. 1987. Sagartia troglodytes (Anthozoa: Actiniaria) consists of two species. Mar. Ecol. Prog. Ser. 41:21-28.

Shenker, J.M. 1984. Scyphomedusae in surface waters near the Oregon coast, May-August, 1981. Estuar. Coast. Shelf Sci. $19: 619-632$.

Shushkina, E.A. and E.I Musayeva. 1983. Marine Biology - the role of jellyfish in the energy system of Black Sea plankton communities. Oceanol. Acad. Sci. USSR 23:92-96.

Sloan, N.A. and C.R. Gunn. 1985. Fishing, processing, and marketing of the jellyfish, (Aurelia aurita L.), from southern British Columbia. Can. Ind. Rep. Fish. Aquat. Sci. 157: 29 p.

Smith, B.L. and D.C. Potts. 1987. Clonal and solitary anemones (Anthopluera) of western North America: population genetics and systematics. Mar. Biol. 94:537546.

Sole-Cava, A.M., J.P. Thorpe and J.G. Kaye. 1985. Reproductive isolation with little genetic divergence between Urticina (=Telia) felina and U. eques (Anthozoa: Actiniaria). Mar. Biol. 85:279-284.

Sole-Cava, A.M. and J.P. Thorpe. 1992. Genetic divergence between colour morphs in populations of the common intertidal sea anemones Actinia equina and A. prasina (Anthozoa: Actiniaria) in the isle of Man. Mar. Biol. $112: 243-252$.

Stoddart, J.A. 1983. Asexual production of planulae in the coral Pocillopora damicornis. Mar. Biol. 76:279-284.

Thorpe, J.P. 1983. Enzyme variation, genetic distance and evolutionary divergence in relation to levels of taxonomic separation. In: Protein polymorphism: adaptive and taxonomic significance, pp. 131-152. Ed. by G.S. Oxford and D. Rollinson. New York: Academic Press.

Uchida, T. 1954. Distribution of scyphomedusae in Japanese and adjacent waters. J. Fac. Sci. Hokkaido Univ. Ser. VI, 12: 209-219. 
Veer, H.W. van der. 1985. Impact of coelenterate predation on larval plaice Pleuronectes platessa and flounder Platichthys flesus stock in the western Wadden Sea. Mar. Ecol. Prog. Ser. 25:229-238.

Veer, H.W. van der and W. Oorthuysen.1985. Abundance, growth and food demand of the scyphomedusa Aurelia aurita in the western Wadden Sea. Neth. J. Sea Res. 19:38-44.

Winer, B.J. 1971. Statistical principles in experimental design, 907 pp. New York: MaGraw-Hill.

Yasuda, T. 1979. Studies on reproductive biology of harmful marine animals - the common jelly-fish, Aurelia aurita, along coast of Wakasa Bay, Japan Sea -. Proc. 7 th JapanSoviet Joint. Symp. Aquaculture, Tokyo, pp. 185-195.

Zar, J.H. 1984. Biostatistical analysis, 718 pp. Englewood Cliffs, New Jersey: Prentice-Hall. 


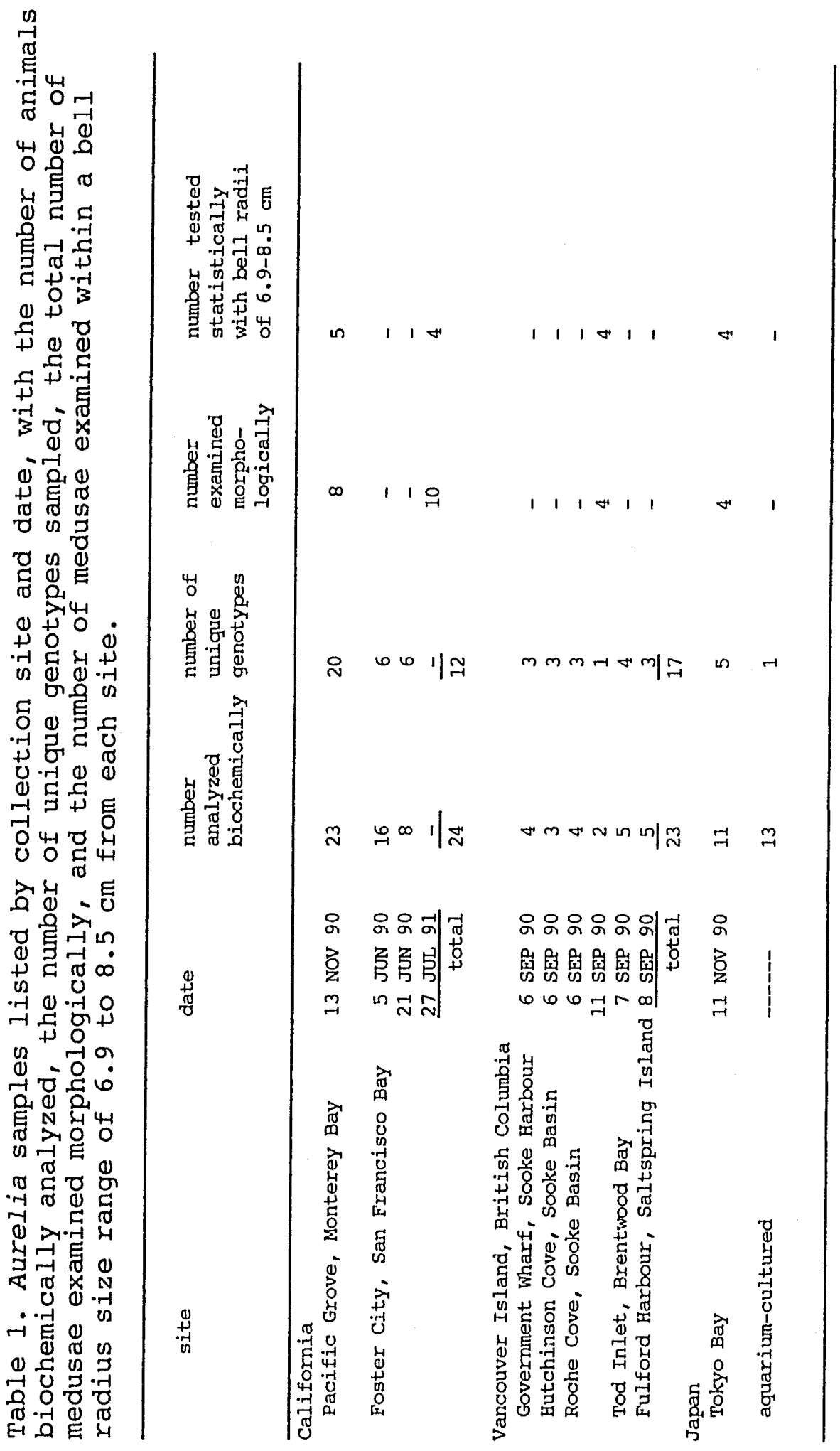


Table 2. Aurelia spp. Allele frequencies at 20 loci from $V I=$ Vancouver Island, British Columbia; $\mathrm{MB}=$ Monterey Bay, Calif.; FC = Foster City, Calif.; TB = Tokyo Bay, Japan; $J=$ aquarium-cultured Tapanese. $\mathrm{n}=$ number of individuals. Alleles of scored loci for $J$ (where $n=1$ ) are listed symbolically as present (Y) or absent (-).

\begin{tabular}{|c|c|c|c|c|c|}
\hline \multicolumn{3}{|c|}{ NORTH AMERICAN GROUP } & \multicolumn{3}{|c|}{ ASIAN GROUP } \\
\hline Locus & VI & MB & FC & $\mathrm{TB}$ & $\mathrm{J}$ \\
\hline $\operatorname{maximum} \mathrm{n}$ & 17 & 20 & 12 & 5 & 1 \\
\hline \multicolumn{6}{|c|}{ A. Polymorphic loci with fixed differences between groups } \\
\hline \multicolumn{6}{|c|}{$I D H-1$} \\
\hline$n$ & 17 & 20 & 12 & 5 & 1 \\
\hline 95 & - & - & 1.00 & 1.00 & $\mathbf{Y}$ \\
\hline 98 & 1.00 & .98 & - & - & - \\
\hline 100 & - & .02 & - & - & - \\
\hline \multicolumn{6}{|l|}{$I D H-2$} \\
\hline$n$ & 13 & 20 & 12 & 5 & 1 \\
\hline 96 & 1.00 & 1.00 & - & - & - \\
\hline 100 & - & - & 1.00 & 1.00 & $\mathrm{Y}$ \\
\hline \multicolumn{6}{|l|}{$P N P$} \\
\hline$n$ & 17 & 20 & 12 & 2 & 1 \\
\hline 93 & 1.00 & 1.00 & - & - & - \\
\hline 98 & - & - & 1.00 & 1.00 & $\mathrm{Y}$ \\
\hline 100 & - & - & - & - & $\mathrm{Y}$ \\
\hline \multicolumn{6}{|l|}{$S O D-1$} \\
\hline$n$ & 10 & 17 & 12 & 2 & 1 \\
\hline 100 & 1.00 & 1.00 & - & - & - \\
\hline no activity & - & - & 1.00 & 1.00 & $\mathrm{Y}$ \\
\hline \multicolumn{6}{|l|}{$S O D-2$} \\
\hline$n$ & 9 & 17 & 12 & 2 & 1 \\
\hline 95 & - & - & 1.00 & 1.00 & $\mathrm{Y}$ \\
\hline 100 & 1.00 & 1.00 & - & - & - \\
\hline \multicolumn{6}{|l|}{$E S T-1$} \\
\hline$n$ & 15 & 18 & 12 & 1 & 1 \\
\hline 95 & - & - & 1.00 & 1.00 & $\mathrm{Y}$ \\
\hline 100 & 1.00 & 1.00 & - & - & - \\
\hline \multicolumn{6}{|l|}{ EST-2 } \\
\hline$n$ & 17 & 20 & 12 & 3 & 1 \\
\hline 96 & 1.00 & 1.00 & - & - & - \\
\hline 100 & - & - & 1.00 & 1.00 & $Y$ \\
\hline
\end{tabular}

B. Polymorphic loci with significant frequency differences between groups CAT

$n$

96

97

99

100

ESTD

$n$

92

96

100

\section{7}

-

.32

.59

.09

17

$-$

.97

.03
20

$-$

.15

.68

.17

20

1.00

$-$
12

.54

.33

.13

$-$

12

.37

.21

.42
3

.17

.83

-

$\begin{array}{ll}5 & 1 \\ .50 & - \\ .30 & Y \\ .20 & \mathrm{Y}\end{array}$

1
-
$Y$
-
-

1
-
$Y$
$Y$

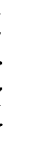


Table 2. Continued.

\begin{tabular}{|c|c|c|c|c|c|c|}
\hline \multicolumn{4}{|c|}{ NORTH AMERICAN GROUP } & \multicolumn{3}{|c|}{ ASIPN GROUP } \\
\hline Locus & & VI & $\mathrm{MB}$ & $\mathrm{FC}$ & TB & $\mathrm{J}$ \\
\hline maximum & $\mathrm{n}$ & 17 & 20 & 1.2 & 5 & 1 \\
\hline \multicolumn{7}{|l|}{ PEPLGG } \\
\hline$n$ & & 17 & 20 & 12 & 5 & 1 \\
\hline 97 & & .41 & .22 & - & - & - \\
\hline 99 & & .38 & .48 & - & - & - \\
\hline 100 & & .21 & .30 & 1.00 & 1.00 & $Y$ \\
\hline \multicolumn{7}{|l|}{ GTDH } \\
\hline n & & 17 & 20 & 9 & 5 & 1 \\
\hline 94 & & - & .38 & 1.00 & 1.00 & $Y$ \\
\hline 98 & & 1.00 & .55 & - & - & - \\
\hline 100 & & - & .07 & - & - & - \\
\hline \multicolumn{7}{|l|}{ PEPLP } \\
\hline $\mathrm{n}$ & & 17 & 17 & 12 & 5 & 1 \\
\hline 98 & & .03 & .03 & 1.00 & 1.00 & $Y$ \\
\hline 100 & & .97 & .97 & - & - & - \\
\hline
\end{tabular}

C. Polymorphic loci with no significant differences between groups $P G D H$

$n$

98

100

$M D H-2$

$n$

94

98

100
16
.97

.03

17

.03

.97

-

\section{0}

0.93

0.07

20

.05

.95

-

\section{2}

1.00

$-$

12

1.00

-

12

1.00

12

1.00

12

1.00

12

1.00

12

$\frac{12}{1.00}$

17

1.00
12

1.00

20 1.00
20
5
1.00
-

5

.90

.10

\section{1
$\mathrm{Y}$}

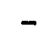

Y

-

PEPGL

\begin{tabular}{llllll}
$n$ & 17 & 20 & 12 & 5 & 1 \\
100 & 1.00 & 1.00 & 1.00 & 1.00 & $\mathrm{x}$ \\
\hline
\end{tabular}


Table 3. Aurelia spp. Matrix of Nei's genetic distances (D) above diagonal and identities (I) below diagonal among four sites: $\mathrm{VI}=$ Vancouver Island, British Columbia; $\mathrm{MB}=$ Monterey Bay, Calif.; FC = Foster City, Calif.; TB = Tokyo Bay, Japan.

\begin{tabular}{ccccc} 
& VI & MB & FC & TB \\
VI & --- & .010 & .750 & .742 \\
MB & .990 & - & .693 & .696 \\
FC & .473 & .500 & -.00 & .009 \\
TB & .476 & .499 & .992 &.--- \\
\hline
\end{tabular}




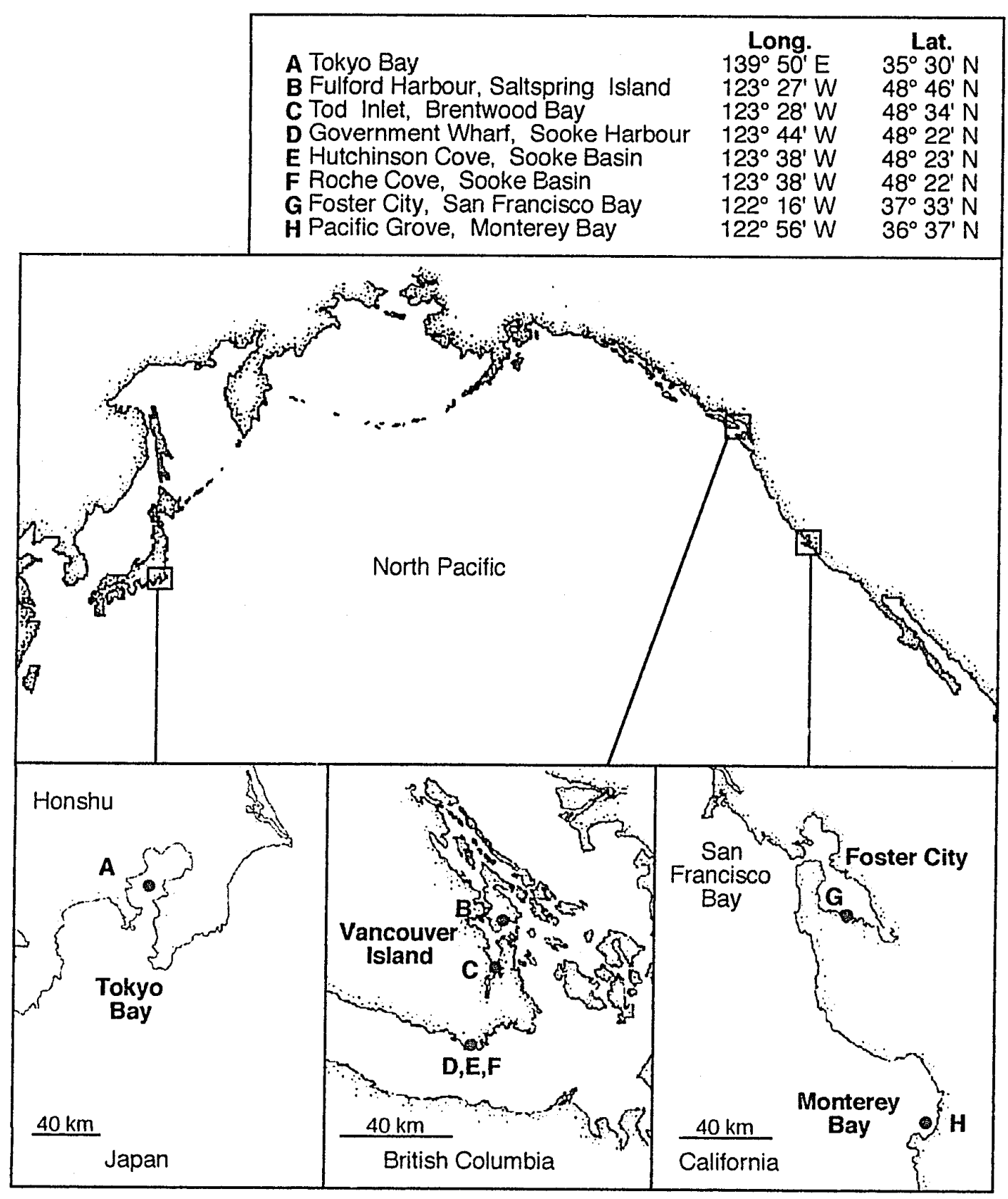

Figure 1. Sampling sites. 


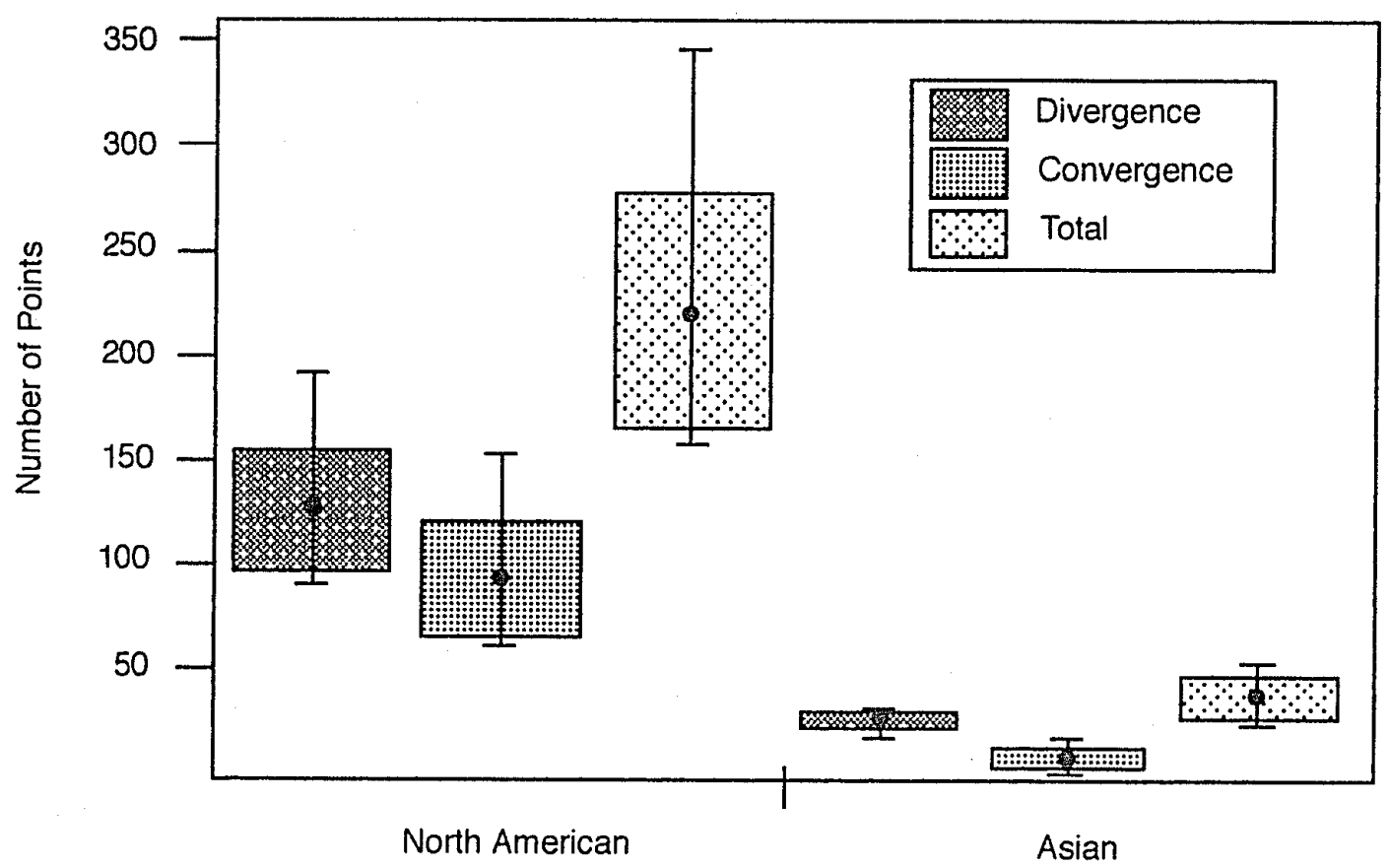

Figure 2. Means (dot), standard errors (box) and range (bar) of radial canal structures of Aurelia medusae within a bell radius size range of 6.9 to $8.5 \mathrm{~cm}$. 


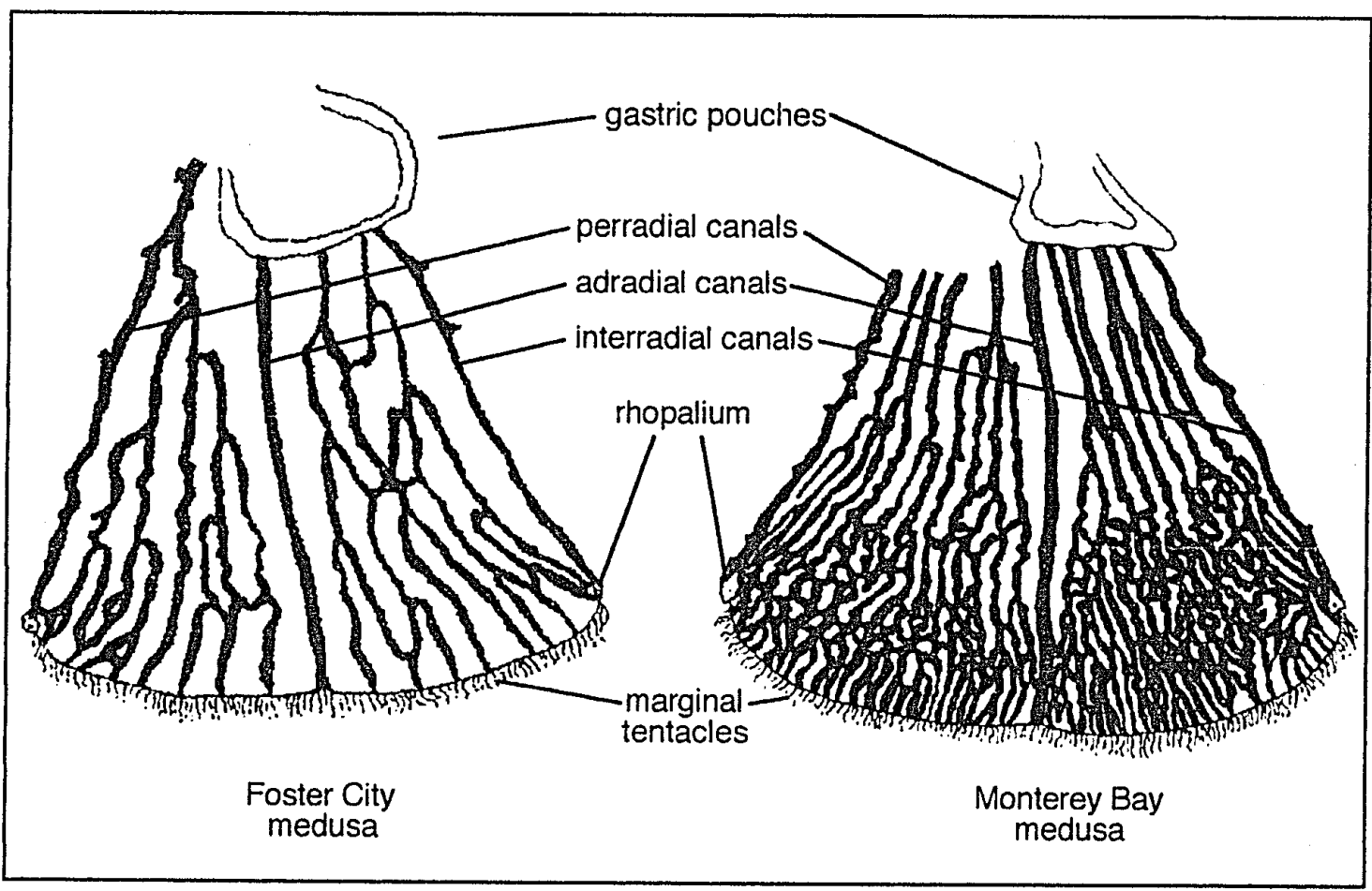

Figure 3. Octants of radial canals of similarly sized medusae from Monterey Bay (bell radius $=7.8 \mathrm{~cm}$; number of divergence points $=192$, convergence points $=153$, and total intersecting points $=345$ ) and Foster City (bell radius $=7.9$ $\mathrm{cm}$; number of divergence points $=30$, convergence points $=12$, and total intersecting points $=42$ ). 


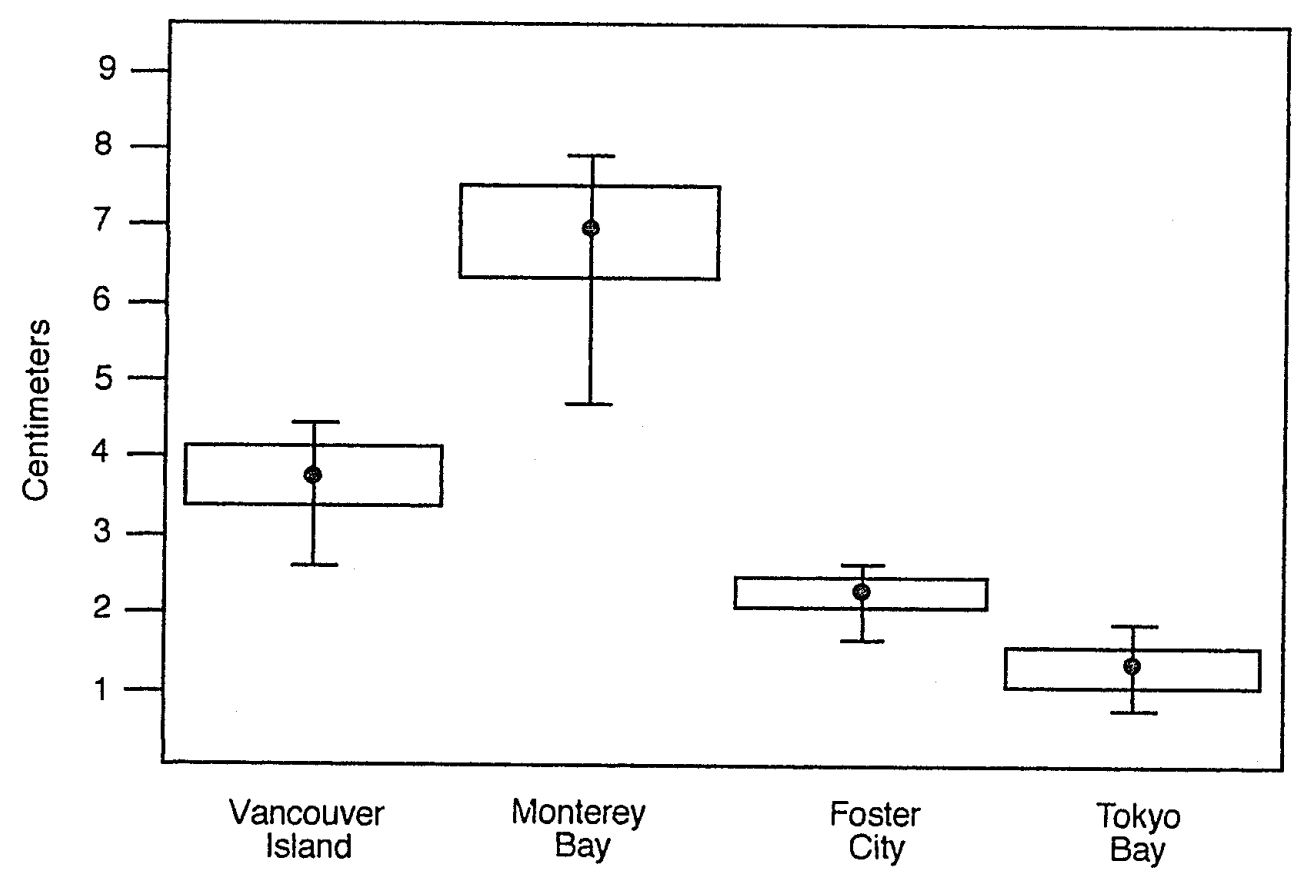

Figure 4. Means (dot), standard errors (box) and range (bar) of manubrium lengths of Aurelia medusae within a bell radius size range of 6.9 to $8.5 \mathrm{~cm}$. 
North American

Asian
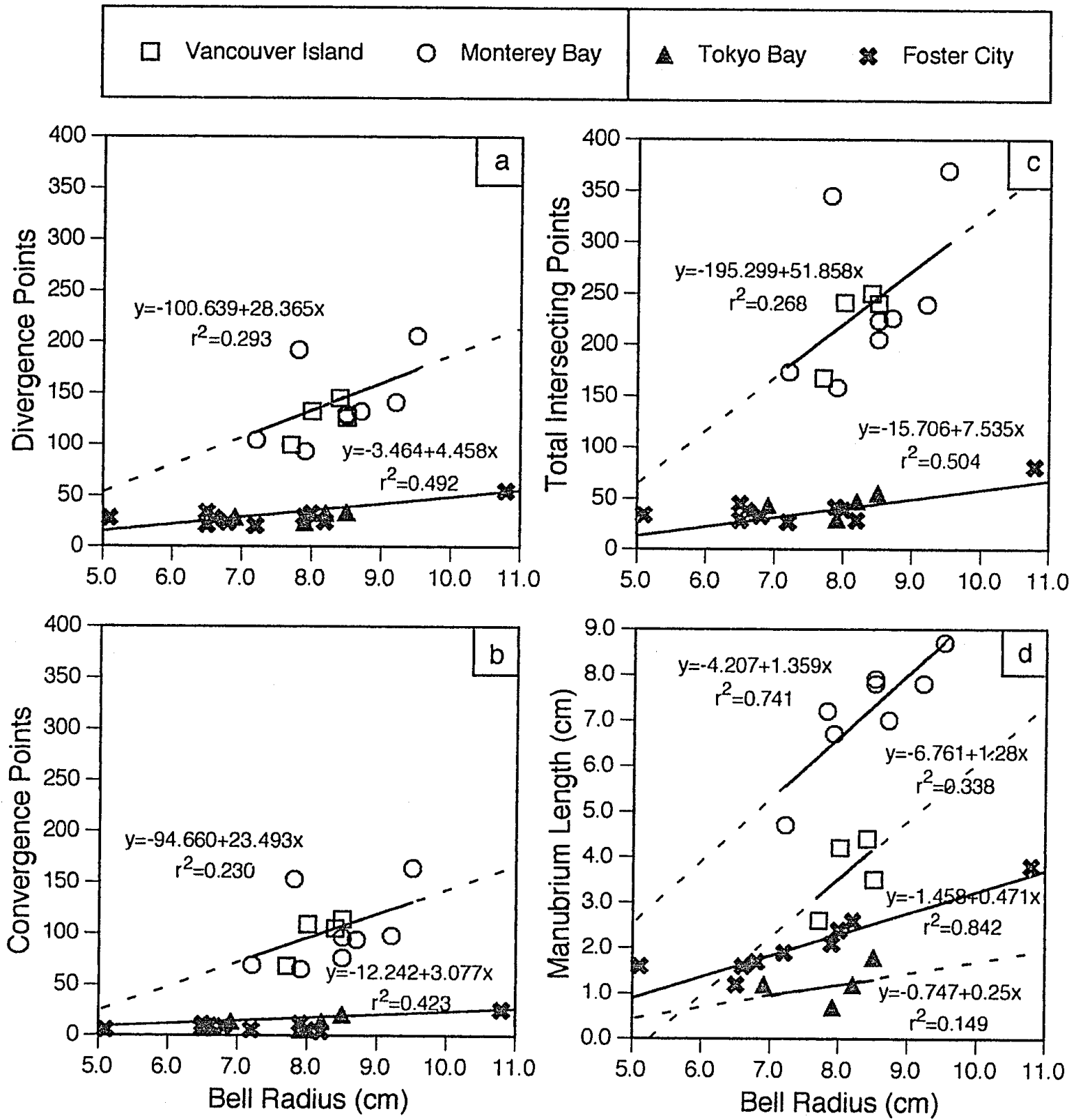

Figure 5. Aurelia medusa divergence (a), convergence (b) and total intersecting (c) points of radial canal octants plotted against bell radius with corresponding regression lines for North American and Asian groups; and inanubrium length (d) plotted against bell radius with corresponding regression lines for each site. 